\title{
African experience of hysterosalpingography abnormalities tubes management by laparoscopy in infertile women
}

\section{Mohamed Fanny*, Edele Aka, Perel Konan, Luc Olou, Abdoul K. Koffi, Stephane Adjoussou, Konan Seni, Apollinaire Horo, Mamourou Kone}

Department of Obstetrics and Gynecology, University and Hospital Center of Yopougon, Abidjan, Côte d'Ivoire

Received: 17 July 2019

Accepted: 09 September 2019

\section{*Correspondence: \\ Dr. Mohamed Fanny, \\ E-mail: mohfanny@yahoo.fr}

Copyright: ( $)$ the author(s), publisher and licensee Medip Academy. This is an open-access article distributed under the terms of the Creative Commons Attribution Non-Commercial License, which permits unrestricted non-commercial use, distribution, and reproduction in any medium, provided the original work is properly cited.

\begin{abstract}
Background: Infertility affects about 80 million people worldwide and one in ten couples. The objective of this study was to report our experience of the contribution of laparoscopy in the diagnostic and prognostic approach of fallopian tubes pathology in infertile women in sub-Saharan Africa.

Methods: We conducted a retrospective study in the Gynecology and Obstetrics unit of Yopougon Teaching Hospital over a 2-year period (January 1, 2017 to December 31, 2018) which included 49 cases of tubo-peritoneal infertility diagnosed by hysterosalpingography (HSG) then laparoscopy procedure.

Results: The average age was 33 years old. $30.6 \%$ were single. $75 \%$ had secondary infertility. $59.2 \%$ had a medical history of abortion. Pelvic Inflammatory Disease and pelvic surgery accounted $84.2 \%$ and 49 respectively. Laparoscopy showed a predominance of distal tubal damage $(66.6 \%)$ whose $47 \%$ hydrosalpinx. Bilateral tubal patency was demonstrated in $77.5 \%$ of our patients during laparoscopy procedure. We observed a sensitivity, a specificity, and a concordance laparoscopy / HSG of 63.6\%, 80\% 63.1\% respectively. Laparoscopy also allowed therapeutic procedures such as adhesiolysis or tubal plasty in 22 patients (44.89\% of our cases). At the end of laparoscopy procedure, 35 patients $(71.42 \%)$ were turned towards IVF.

Conclusions: Laparoscopy allows an assessment of tubal abnormalities revealed by hysterosalpingography and the fertility prognostic as well as better therapeutic approach in management of tubal infertility.
\end{abstract}

Keywords: Fallopian tubes abnormalities, Hysterosalpingography, Infertility, In-vitro fertilization, Laparoscopy

\section{INTRODUCTION}

Infertility affects about 80 million people worldwide and one in ten couples. ${ }^{1}$ The causes are female in $30 \%$, male in $30 \%$ and both in $40 \%$ of cases. ${ }^{2}$ Female infertility may be due to an abnormality affecting the uterus, fallopian tubes, or ovaries. In Africa, tubal lesions are the leading cause of female infertility (60 to $70 \%$ ) because of the high incidence of pelvic inflammatory disease. ${ }^{3}$ This is responsible for tubo-peritoneal adhesions and tubal obstruction. In front of these tubal lesions, laparoscopy has a double diagnostic and therapeutic interest. However, some tubal abnormalities limit the therapeutic scope of laparoscopy and therefore do not improve the prognosis. This situation is worrying in Africa, where patients consult late at a stage where the lesions are old and severe. It is a public health problem.

In recent years, we have systematically performed laparoscopy in infertile women with radiologic tubal abnormalities. The present study allows us to report the contribution of laparoscopy to tubal abnormalities 
detected by hysterosalpingography in our professional environment. The specific objectives of the work are to determine the epidemiological profile of patients presenting tubal abnormalities to hysterosalpingography, to specify the radiological lesions observed and to describe the type of abnormalities observed at laparoscopy in comparison with radiological lesions. The main objective is to to contribute to an improvement of the therapeutic approach of infertility in our context.

\section{METHODS}

Our study took place in the gynecology and obstetrics department of the Yopougon University Hospital (Abidjan, Ivory Coast) where we have a gynecological endoscopy unit. This was a retrospective study covering a period of 2 years, from January $1^{\text {st }}, 2017$ to December $31^{\text {st }}, 2018$.

\section{Inclusion criteria}

- Our work concerned all the patients who came to consult our service for desire of maternity and for whom a laparoscopy was performed in front of pathological images viewed at the hysterosalpingography.

\section{Exclusion criteria}

- The patients who did not have hysterosalpingography before laparoscopy

- The patients in whom the indication for laparoscopy was not tuboperitoneal infertility

- The second-look laparoscopy.

For our study, we selected 49 patients based on inclusion criteria and exclusion criteria.

The laparoscopy procedures were performed by only one senior gynaecologist.

The data collection instrument was a survey form. This sheet allowed us to obtain information from the operation of the patient's medical files, the records of the operating reports and the consultation records.

\section{The variables studied}

We studied as parameters: The socio-demographic characteristics of the patients, their medical, gynaecological obstetrics and surgery history. To make the prognostic evaluation of the tubal lesions, we applied the Mage operability scores.

\section{Statistical analysis}

Data was processed on Windows XP professional using software Microsoft Word 2003 and Microsoft Excel 2003. Statistical analyzes were performed using the Win stata software.

\section{RESULTS}

\section{Epidemiological features and medical history}

The average age of our patients was 33.2 years old (23$41)$. Women older than 35 years accounted for more than $1 / 3(34.7 \%)$ ). $30.6 \%$ single. More than half (57.1\%) had no stable source of income. About half $(49 \%)$ were in liberal activities (hairdresser, dressmaker). Half of the patients $(49 \%)$ had a pelvic inflammatory disease and $14.3 \%$ an ectopic pregnancy. We noted a history of myomectomy and salpingectomy were the most important $(68.4 \%)$. The other parameters of medical history are summarized in Table 1.

Table 1: Distribution of 49 women according to epidemiological features and medical history.

\begin{tabular}{|lll|}
\hline $\begin{array}{l}\text { Epidemiological } \\
\text { features }\end{array}$ & Numbers & $\begin{array}{l}\text { Frequency } \\
(\%)\end{array}$ \\
\hline Age (years) & 5 & 10.2 \\
\hline$\leq 30$ & 27 & 55.1 \\
\hline $31-35$ & 15 & 30.6 \\
\hline $36-40$ & 2 & 4.1 \\
\hline$\geq 40$ & & \\
\hline Marital status & 15 & 30.6 \\
\hline Single & 34 & 69.4 \\
\hline Couple & & \\
\hline Profession & 21 & 42.9 \\
\hline Employee & 24 & 49 \\
\hline Liberal activity & 4 & 8.1 \\
\hline No occupation & & \\
\hline Medical History & & \\
\hline Gynecological & 24 & 49 \\
\hline $\begin{array}{l}\text { Pelvic inflammatory } \\
\text { disease }\end{array}$ & 14 & 28.5 \\
\hline Uterine fibroids & 07 & 14.3 \\
\hline Ectopic pregnancy & 02 & 4.1 \\
\hline Endometriosis & & 36.8 \\
\hline Surgical & 7 & 10.5 \\
\hline Salpingectomy & 6 & \\
\hline Myomectomy & & \\
\hline Appendicectomy & 2 & \\
\hline Others & & \\
\hline
\end{tabular}

\section{Abnormalities with hysterosalpingography and findings during laparoscopies procedures}

The distal tubal damages were the most numerous $(61.1 \%)$ dominated by hydrosalpinx (42.8\%). Hysterosalpingography showed bilateral tubal damages in $59.1 \%$ of cases. The most observed findings were adhesions in 36 patients $(73.4 \%)$ and hydrosalpinx in 23 cases $(47 \%)$. The methylene blue tubal patency test was performed in 38 patients. That is an achievement rate of $77.5 \% .11$ patients did not undergo this test because of an important adhesion or because of a chromotubation. The methylene blue test has overturned the tubal obstruction 
diagnosed in 05 patients during hysterosalpingography (Table 2). Adhesive lesions were evaluated in 29 patients (Table 3).

Table 2: Distribution of 49 women according to hysterosalpingography abnormalities and findings during laparoscopies procedures.

\begin{tabular}{|c|c|c|}
\hline $\begin{array}{l}\text { Hysterosalpingography } \\
\text { findings }\end{array}$ & Numbers & $\begin{array}{l}\text { Frequency } \\
(\%)\end{array}$ \\
\hline \multicolumn{3}{|c|}{ Type of abnormalities tubes } \\
\hline Hydrosalpinx & 21 & 42.9 \\
\hline Tubal Phimosis & 9 & 18.4 \\
\hline endometriosis & 1 & 2 \\
\hline Proximal tubal occlusion & 18 & 36.7 \\
\hline \multicolumn{3}{|l|}{ Topography } \\
\hline Unilatéral & 13 & 26.5 \\
\hline Bilatéral & 29 & 59.2 \\
\hline Alone fallopian tube & 7 & 14.3 \\
\hline \multicolumn{3}{|l|}{ State of mucosal folds } \\
\hline Preserved & 17 & 54.8 \\
\hline Impaired & 9 & 29 \\
\hline Absent & 5 & 16.1 \\
\hline \multicolumn{3}{|l|}{ Laparoscopy findings } \\
\hline \multicolumn{3}{|l|}{ Type of lesions } \\
\hline Adhesions & 36 & 73.4 \\
\hline Hydrosalpinx & 23 & 47 \\
\hline Phimosis & 16 & 32.7 \\
\hline Endometriosis & 4 & 8.2 \\
\hline \multicolumn{3}{|c|}{ Methylene blue test (tubal patency) } \\
\hline Bilateral Occlusion & 12 & 31.6 \\
\hline Unilateral Occlusion & 17 & 44.7 \\
\hline Single fallopian tube & 04 & 10.5 \\
\hline Bilateral tubal patency & 05 & 13.2 \\
\hline \multicolumn{3}{|l|}{ State of the tubal wall } \\
\hline Sclerotic & 05 & 12.2 \\
\hline Thin & 11 & 26.8 \\
\hline Normal & 25 & 61 \\
\hline
\end{tabular}

Table 3: Assessment of level adhesions in 29 women.

\begin{tabular}{|lllll|}
\hline & \multicolumn{3}{c|}{ Palmer classification } \\
\hline $\begin{array}{l}\text { Adhesion score } \\
\text { according to MAGE }\end{array}$ & $\begin{array}{l}\text { Type } \\
\text { a }\end{array}$ & $\begin{array}{l}\text { Type } \\
\text { b }\end{array}$ & Type & Total \\
\hline Stade I $(1-6)$ & 5 & 2 & 0 & $\mathbf{7}$ \\
\hline Stade II $(7-15)$ & 5 & 3 & 5 & $\mathbf{1 3}$ \\
\hline Stade III $(>16)$ & 0 & 5 & 4 & $\mathbf{9}$ \\
\hline Total & $\mathbf{1 0}$ & $\mathbf{1 0}$ & $\mathbf{9}$ & $\mathbf{2 9}$ \\
\hline
\end{tabular}

\section{Surgical treatment}

A surgical procedure was performed in 33 women; for the other patients, it was not considered necessary to make a gesture. Adhesiolysis was the most frequently performed procedure (Table 4).

Table 4: Distribution of 33 women according to the type surgical treatment.

\begin{tabular}{|lll|}
\hline Surgical treatment & Numbers & Frequency (\%) \\
\hline Adhesiolysis & 9 & 27.3 \\
\hline Fimbrioplasty & 6 & 3 \\
\hline Salpingectomy & 6 & 3 \\
\hline Néosalpingostomy & 4 & \\
\hline $\begin{array}{l}\text { Adhésiolysis + Tubal } \\
\text { plasty }\end{array}$ & 8 & 24.2 \\
\hline Total & $\mathbf{3 3}$ & $\mathbf{1 0 0}$ \\
\hline
\end{tabular}

\section{Hysterosalpingography versus laparoscopy concerning tubal patency}

The methylene blue test in 38 patients confirmed tubal obstruction in 24 patients: 12 had bilateral obstruction, 8 had unilateral obstruction, and 4 patients with a history of salpingectomy had an occlusion on the single fallopian tube (Table 5).

Table 5: Sensibility, specificity and predictive values of tubal patency on hysterosalpingography.

\begin{tabular}{|lllll|l|}
\hline \multicolumn{1}{|c|}{ Methylene blue test } & $\begin{array}{l}\text { Bilatérale } \\
\text { occlusion }\end{array}$ & $\begin{array}{l}\text { Unilatérale } \\
\text { occlusion }\end{array}$ & $\begin{array}{l}\text { No } \\
\text { occlusion }\end{array}$ & $\begin{array}{l}\text { Not } \\
\text { performed }\end{array}$ & Total \\
\hline Bilatérale occlusion & 12 & 09 & 01 & 07 & 29 \\
\hline Unilatérale occlusion & - & 08 & 02 & 03 & 13 \\
\hline Single fallopian tube & - & 04 & 02 & 01 & 07 \\
\hline Total & $\mathbf{1 2}$ & $\mathbf{2 1}$ & $\mathbf{0 5}$ & $\mathbf{1 1}$ & $\mathbf{4 9}$ \\
\hline
\end{tabular}

\section{DISCUSSION}

\section{Epidemiological features}

The average age of our patients was similar to Belley in Cameroon and Rachdi in Tunisia who found an average age of 34.8 and 31 years respectively., ${ }^{4,5}$ This relatively high average age highlighted in these studies could reflect the long delay by patients to consult a referral center.

Mostly in Africa, women going to hospital after a long history of unsuccessful attempts at traditional medicine. 
Otherwise, the life habits changed and its can lead women to delay their motherhood; they prefer her career to pregnancy project. In addition, laparoscopy is not a free care and that a barrier to management patient. Only $42.9 \%$ of our patients had paid employment and more than half of the patients had no stable income. The low economic level favors the occurrence of certain conditions having in common precariousness as a risk factor. For example, the genital infections. Thus, we noted that $49 \%$ of our patients had a history of pelvic inflammatory disease (PID). The frequently of tubal infertility among the causes of female infertility in Africa is related to the very high frequency of inflammatory pelvic disease (PID). ${ }^{3}$ Salpingitis can lead to fallopian tube occlusion or the impossibility of the uptake of the ovule because of pelvic adhesions, or because of tubal epithelium alteration. ${ }^{6}$ The resurgence of sexually transmitted infections (STI) and salpingitis in Africa is linked to HIV/AIDS infection. In addition to adhesions caused by PID, pelvic surgery by laparotomy and peritoneal endometriosis are other adhesion risk factors.

A history of pelvic surgery was noted in $24.4 \%$ of patients. Postoperative adhesions are most often of type $b$ or $\mathrm{c}$ according to Raoul Palmer's classification. ${ }^{7}$ However, according to Bowman TM cited by Reyftmann $\mathrm{L}$, there is no correlation between mucosal scores and adherence scores, and the endosalpinx is often of high quality as in endometriosis, unlike Infectious tubal processes. $^{8}$ The primary prevention of postoperative adhesions requires intraoperative precautions, including a correct abdominal toilet. There are GoreTex-type mechanical barriers (nonabsorbable plaque to be applied to the injured region) and Seprafilm (resorbable membrane forming a gel after 48 hours) have shown efficacy in preventing postoperative adhesions in benign gynecological surgery. ${ }^{8}$ But these mechanical barriers are not unanimous within all surgical teams.

\section{Radiological features}

Hysterosalpingography showed essentially distal fallopian tubes damages $(61.1 \%)$ dominated by hydrosalpinx $(42.8 \%)$. This fact is probably due to the high proportion of PID history (49\%) in our patients. The radiological appearance of the tubal mucosal folds was used for assessment of the tubal mucosa. The quality of the tubal mucosa is important in the evaluation of Mage's distal tubal score. ${ }^{7}$

\section{Laparoscopic data}

The preponderance of adhesions observed in our series could be related to the risk factors found in our patients, of which $49 \%$ had PID history, $84.2 \%$, pelvic surgery history, and $8.2 \%$, peritoneal endometriosis. According to Marana R cited by Reyftmann L, endosalpinx is often of high quality in case of adhesions due to endometriosis and pelvic surgery. ${ }^{8}$ Laparoscopy overturned tubal obstruction in 5 patients and led to the diagnosis of tubal spasm occurring during hysterosalpingography procedure. While most laparoscopists consider the occurrence of a rare ostial spasm under general anesthesia during laparoscopy, we noted the incident is mention in $17 \%$ of cases. ${ }^{9}$

\section{The contribution of laparoscopy in the prognostic evaluation of the fallopian tubes}

In the absence of an evaluation of the tubal mucosa by ampullary tuboscopy, the study of the tubal wall and the tubal horn, which are known to be a reflection of the condition of the ampullary mucosa, was emphasized. ${ }^{10}$ For Brosens and Gomel cited by Cornier, the proportion of hair cells present on the fringes of the fimbria is a major prognostic element of the tubal function. ${ }^{10}$ Brux and Palmer cited by the same author showed that if fringe architecture was respected (case of congestive and exudative salpingitis), the rate of intrauterine pregnancies was $34 \%$ with $12 \%$ ectopic pregnancies; on the other hand, if the fringes are atrophic or stretched or confined by synechiae, the rates are reversed with $8 \%$ of intrauterine pregnancies and $38 \%$ of extra uterine pregnancies. Although some authors find it invasive, ampullary tuboscopy during laparoscopy allows a more detailed evaluation of the ampullary mucosa and the establishment of a mucosal score that will guide the therapeutic. ${ }^{11}$ A grade IV or V mucosal score indicates restorative laparoscopic surgery for distal tubal lesions. ${ }^{8}$

Prognostic evaluation of the fallopian tubes was performed on the basis of Mage's tubal and adherent scores. ${ }^{7}$ This assessment according to the Mage scores determines the therapeutic choice during laparoscopy.

\section{Laparoscopy contribution in management of tubal abnormalities}

Adhesiolysis was the most common procedure, followed by salpingoneostomy and fimbrioplasty. The contraindications of distal tubal plasty and adhesiolysis are well known. ${ }^{8}$ Salpingectomy was sometimes necessary, if conservative surgery cannot be performing or if there is an adnexe inflammatory. ${ }^{8}$ In addition, salpingectomy improve implantation rate of IVF. Indeed, the Scandinavian studies of Strandell cited by Pouly, clearly showed that the benefit of salpingectomy exists in case of voluminous hydrosalpinx. ${ }^{12}$ Several theories have been suggested to explain the deleterious effect of hydrosalpinx on the results of IVF (persistent inflammation, secretion of cytokines, fluid toxicity of hydrosalpinx). The main theory according to Pouly is the regurgitation of the fluid of the hydrosalpinx in the uterine cavity which disturbs mechanical the implantation of the egg. ${ }^{12}$

\section{CONCLUSION}

The laparoscopy procedure is recognized in the diagnosis of fallopian tubes abnormalities. Methylene blue tubal 
permeability test and ampullary tuboscopy strength this exploration. Sometimes, IVF is necessary but it's no free care and constitute a barrier.

Funding: No funding sources

Conflict of interest: None declared

Ethical approval: The study was approved by the Institutional Ethics Committee

\section{REFERENCES}

1. Brzakowski M, Lourdel E, Cabry R, Oliéric MF, Claeys C, Devaux A. Epidemiology of the infertile couple. J Gynecol Obstet Biol Reprod. 2009;38 Spec No. 1-2:F3-7.

2. Hamamah S, Anahory $\mathrm{T}$, Ferrière A, Loup V, Reyftmann L, Dechaud H. Therapeutic solutions for male infections. J Gynecol Obstet Biol Reprod. 2009;38 Spec No. 1-2:F58-F64.

3. Dia JM, Yao I, Guié P, Bohoussou E, Nguessan E, Oyelade $\mathrm{M}$, et al. Epidemiological and etiological aspects of infertile couples in Abidjan. Rev Int Sc Méd. 2016;18(1):22-6.

4. Belley PE, Tchente NC, Nguemgne C, Nana NT, Taila W, Banag E. Female infertility at Douala General Hospital: epidemiological and radiological aspects (about 658 cases). J Afr Imag Méd. 2015;7(2):16-23.

5. Rachdi R, Messaoudi F, Ben TY, Basly M, Chlayh M. Contribution of operative laparoscopy in the treatment of female infertility. Tunisie Médicale. 2004;82:837-42.

6. Mårdh PA. Tubal factor infertility, with special regard to chlamydial salpingitis. Curr Opin Infect Dis. 2004;17(1):49-52.
7. Mage $\mathrm{G}$, Bruhat MA, Bouquet de la jolinière $\mathrm{J}$, Canis M, Charand S, Dellenbach P, et al. Tubal operability score. Extract from the XXXIIIth French Assize of Gynecological - Poitiers 1987, 93-6 Masson (Paris).

8. Reyftmann L, Dechaut C, Amar A. What place is left for reproductive surgery? J Gynecol Obstet Biol Reprod. 2009;38 Spec No.1-2:F35-F42.

9. Kehila M, Ben Hmid R, Khedher BS, Mahjoub S, Bedis MC. Concordance and contributions of hysterosalpingography and laparoscopy in exploration of pelvic and tubal infertility. Pan Afr Med J. 2014;17:126.

10. Cornier E, Feinsech MJ, Bouccara L. Fibrotuboscopy ampullary. J Gynecol Obstet Biol Reprod. 1984;13(1):49-53.

11. Brosens I, Boekx W, Delattin P, Puttemans P, Vasquez G. Salpingoscopy: a new pre-operative diagnostic tool in tubal infertility. $\mathrm{Br} \mathrm{J}$ Obstet Gynaecol. 1987;94:768-73.

12. Pouly JL. What are the elements of the choice between surgery and IVF in infertility? Contracep Ferttil Stéril. 1992:277-280.

Cite this article as: Fanny M, Aka E, Konan P, Olou L, Koffi AK, Adjoussou S, et al. African experience of hysterosalpingography abnormalities tubes management by laparoscopy in infertile women. Int $\mathbf{J}$ Reprod Contracept Obstet Gynecol 2019;8:4271-5. 